\title{
A MULHER NEGRA E A BUSCA PELA INTELECTUALIDADE: DERRUBANDO BARREIRAS E CONSTRUINDO CAMINHOS
}

\author{
Neuza Maria Sant Anna Oliveira
}

\section{Para inicio de conversa...}

A voz da minha bisavó ecoou (...)

Ecoou lamentos

de uma infância perdida.

A voz de minha avó

ecoou obediencia

aos brancos-donos de tudo.

$A$ voz de minha mãe ecoou baixinho revolta (...).

A minha voz ainda ecoa versos perplexos(...).

A voz de minha filha

recolhe todas as nossas vozes

recolhe em si

as vozes mudas caladas

engasgadas nas gargantas.

A voz de minha filha

recolhe em si

a fala e o ato.

(Vozes-mulheres, de Conceição Evaristo)

Quando me dedico à escrita deste texto, recolho em si a fala e o ato de todos os outros que me antecederam, e faço com que as palavras alheias se tornem minhas. Esse texto nada mais é do que o conjunto de palavras alheias que se tornaram minhas. Palavras de Nilma Lino Gomes, bell hooks, Bakhtin, Benjamin, Joice, entre muitos outros.

Esse texto é um pequeno fragmento do texto de minha dissertação intitulada "Mulheres negras intelectuais da periferia", defendia de março de 2014. Onde realizo uma discussão sobre as trajetórias acadêmicas de algumas mulheres que nasceram e vivem na Baixada Fluminense. Para essa conversa elegi apenas uma das três histórias ii que ouvi, entretanto em alguns momentos as falas de outras mulheres que encontrei surgiram no decorrer do texto. A história de Joice, uma professora da rede municipal de um município da Baixada Fluminense é apenas uma das muitas histórias de empoderamentos, espalhadas pelo mundo, entretanto os nossos caminhos se cruzaram e foi a parti do encontro com Joice e com as outras mulheres que me impulsionaram a escrever e contar histórias de mulheres negras intelectuais. 


\section{O encontro com o outro e o papel do narrador}

Ao longo desta pesquisa, acabamos por nos reconhecer nas palavras de Marília Amorin (2004): toda pesquisa no campo das ciências humanas é um encontro com o outro. Um encontro entre dois centros de valores. $\mathrm{O}$ outro é o espelho que nos mira enquanto o admiramos; nos faz ver que não podemos viver sozinhos, ver a nossa própria face. O outro é espelho de minha alma; o outro são meus olhos, miro-me e me vejo. O outro são meus ouvidos, me escuto quando falo com ele, me reconheço quando ele fala comigo. Enfim, no outro é que eu me admiro, me ouço, me perco e me encontro. Penso, me vejo, me reflito na magia de seu espelho. Eu também sou espelho do outro.

Talvez tenha sido essa, desde o início, nossa maior inquietação: ouvir e contar histórias e, a partir delas, nos descobrir no outro. Parece que foi isto que acabou nos acontecendo. De cada conversa, de cada encontro, saíamos, eu e minhas interlocutoras, alteradas. As mesmas, mas não exatamente as mesmas, porque diferentes daquelas que haviam entrado no diálogo. Em cada encontro, em cada história que nos foi contada, uma lição de vida. Em cada uma dessas narradoras, uma face da mulher negra, uma singularidade na pluralidade das mulheres. No fundo, outra face minha. Elas são eu. Enfim, poder-se-ia concluir que esses três encontros foram o bastante para confirmar as palavras de Bakhtin: é com o outro que passamos à existência concreta, que verdadeiramente passamos a existir. É o outro que nos concede a existência, que nos ilumina com seu olhar. Somos no outro sem, no entanto, deixar de sermos sempre em nós mesmas.

Neste empreendimento, de descoberta de mim e do outro, as palavras de Benjamin (1985) foram as que me orientaram sobre a natureza e o papel do narrador. Para ele, o trabalho do narrador é tal qual o trabalho do artesão: um trabalho manual, árduo e diário, cuja matéria-prima é retirada da experiência vivida pessoalmente ou que foi, por outro, relatada. Para Benjamin, o papel do narrador não é nada mais que isso: passar adiante suas experiências, vividas ou relatadas, para que sejam incorporadas à experiência de seus ouvintes.

Penso que é isto que estamos tentando fazer aqui: passar adiante as histórias dessas três mulheres com a intenção de que outras mulheres possam se reconhecer nelas, ampliando, assim, suas próprias experiências. E só assim podemos compreender o nosso esforço e o nosso trabalho com as narrativas. Elas, diferentemente das explicações científicas universais abstratas, são encarnações que não nos oferecem nenhuma explicação. Elas apenas apresentam a própria vida como é ou está sendo, e sobre isto só podemos tentar compreender, 
mas jamais explicar. Elas explicam-se por si mesmas. Quem não entendê-las é porque ainda não percebeu. Cabe-nos relê-las ou contá-las de novo. Elas são discursos do vivido. Como tais, não nos exigem explicações teóricas, mas respostas da vida.

A vida só aceita respostas que venham da própria vida. A vida, queiramos ou não, é ato responsável. Por isso, não a compreendemos teoricamente. Só podemos compreender o nosso dever ser em relação a ela. Como ato singular. Como ato meu. Assim como nos faz ver Bakhtin na passagem a seguir:

Eu ajo com toda a minha vida, e cada ato singular e cada experiência que vivo são um momento do meu viver-agir. Tal pensamento, enquanto ato, forma um todo integral: tanto o seu conteúdo-sentido quanto o fato de sua presença em minha consciência real de um ser humano singular, precisamente determinado e em condições determinadas - ou seja, toda a historicidade concreta de sua realização -; este dois momentos, portanto, seja do sentido, seja do histórico-individual (factual), são dois momentos unitários e inseparáveis na valoração deste pensamento como meu ato responsável (BAKHTIN, 2010, p. 44).

Para nós, o narrador de Benjamin nada mais é (e só isto nos basta) que o que acabamos de ler nas palavras acima. O narrador é aquele que assume um ponto de vista sobre a vida com a inteireza de sua própria vida enquanto ato responsável ou de responsabilidade sua. O narrador não é um cientista, um historiador, um sociólogo, um antropólogo, tampouco um artista tal qual um romancista. Sua matéria é o acontecer da própria vida. Daí, para Benjamin (1985), ser bom narrador aquele que narra os acontecimentos, sem distinguir entre os grandes e os pequenos. O autor considera que o bom narrador "é aquele que leva em conta a verdade de que nada do que um dia aconteceu pode ser considerado perdido para a história". (BENJAMIN, 1985, p.223)

E foi com este bom conselho que nos lançamos: fomos à busca de algumas histórias sem, no entanto, nos importarmos se eram histórias grandes ou pequenas, mas que não podem ser perdidas para se contar a história das mulheres. Histórias de mulheres que vivem na Baixada Fluminense. Histórias que, sabemos, não se esgotam; tampouco se esgota o tema. Mesmo que escolhêssemos cem mil mulheres, o assunto não se esgotaria, pois mulheres são muitas, são milhares. Em cada uma, mil histórias. Em cada história, mil mulheres. Histórias que, por serem histórias, acontecem uma única e só vez. Aconteceu com esta, não com aquela, e vice-versa. 
Portanto, em momento algum passou por nossa cabeça que essas mulheres representem a condição de todas as mulheres negras da Baixada Fluminense. Elas sequer são, dada à exiguidade dos números, um recorte do segmento das mulheres negras estudantes universitárias e aspirantes a uma vida acadêmica. Neste sentido, elas não representam todas as mulheres. Elas não representam pessoa ou segmento social algum; elas só podem representar a si mesmas.

Então, vamos a elas, para ouvir suas narrativas, as pequenas e grandes histórias de suas vidas. Vamos ao encontro de uma dessas mulheres que, generosamente, me concederam o direito de palavra, o direito de existir.

\section{A história do encontro com Joice ${ }^{\text {iii }}$.}

Cheguei cedo. Aliás, já faz tempo que não consigo a façanha de chegar cedo a lugar algum. Mas a culpa não é só minha, não. A culpa também é desse sistema de transporte urbano, desse trânsito enlouquecedor que faz de todo passageiro um passageiro da agonia. Um coelhinho apressado como aquele da história de Alice, que anda sempre apressado perguntando as horas. De modo que nem eu mesma acreditava que já estava ali, já sentada com caneta, bloco de anotações e um pequeno gravador, à espera de minha primeira entrevistada.

Embora tivesse chegado a tempo e à hora, estava ansiosa, nervosa. Estava quieta e inquieta. Uma pilha de nervos e com o coração batendo a mil por hora. Precisava me acalmar ou parecer calma, deixar de suar frio nas mãos. Deixar de ficar com aquela boca seca. Deixar de ficar com medo, qual bicho no escuro com os olhos arregalados, assustada, apreensiva e com o coração quase saindo pela boca.

Para amenizar minha situação, pus-me a desenhar e a escrever algumas perguntas. Perguntas que não tinham nem pé nem cabeça, pois eram coisas que não tinham nada a ver. Ou tinham? Ali, naquele momento de expectativa e de aflição, elas apenas serviam para passar o tempo.

Todavia, foi nesse passatempo que me ocorreu a brilhante ideia: deixar que as coisas acontecessem naturalmente. Caso elas não dessem certo daquela vez, não seria tão grave assim. Haveria sempre a oportunidade e a possibilidade de marcarmos outro encontro e, portanto, nem tudo estaria perdido para a história. Procurando convencer-me e escapar 
daquela situação apertada, pensei nas palavras de Benjamin: "nada do que um dia aconteceu pode ser considerado perdido para a história”. (BENJAMIN, 1985, p.223)

Foi pensando nas palavras de Benjamin que acabei por me convencer de que aquele encontro que estava prestes a acontecer não seria um tempo jogado fora, um tempo perdido, mas um tempo de se aprender. Um tempo de conhecer a mim e ao outro, a quem ansiosamente aguardava, mas que, devido a minha situação de extrema ansiedade, parecia não chegar nunca para aquele encontro marcado. Será que ela vem? Será que houve algum problema com o trânsito, com algum membro da família? Essas e outras perguntas do mesmo tipo me assaltavam a alma, me dilaceravam a carne; roía as unhas.

Nesse estado de excitação exagerada, quase à beira de um ataque de nervos, me dei conta de que os encontros marcados, por serem formais e ritualísticos, não são a melhor estratégia de conversar e de conhecer pessoas. Precisava, então, me acalmar, desacelerar e não ir diretamente ao assunto. Deixar que ele mesmo, o assunto, se fizesse presente no fluir da própria conversa. Conforme aprendi com Hannah Arendt (2010), no diálogo e no encontro com outro, podemos dar ou provocar o início, mas nunca prever ou controlar o desfecho, os resultados. Hannah Arendt também me deixou um pouco mais calma. Mas só um pouquinho.

O fato é que, naquele exato momento me dei conta do óbvio: que a metodologia que havíamos proposto não podia ficar apenas como uma teoria no papel. Ela precisava ser colocada em prática e sua prática era a própria conversa, o melhor caminho para se travar conhecimento com os outros. Esquecer que esse era um encontro marcado, fingir que era um encontro ao acaso, um falar por falar até nos encontrarmos ou nos colocarmos mais naturalmente, o mais informal possível.

Os encontros marcados, embora necessários, não o são a melhor estratégia de pesquisa, pois neles, diferentemente dos encontros cotidianos, criamos uma expectativa além da necessária. Já nos encontros ao acaso, tais preocupações não existem. Eles acontecem no fluxo e no acontecer da própria vida, sem regras previamente estabelecidas, sem hora marcada, data e local. Encontros marcados, por serem marcados, podem ser desmarcados. Encontros informais são inevitáveis, estão fora de qualquer controle. Daí dei de imaginar e de fingir que este encontro, embora marcado com data, hora e local, também poderia ser um encontro, assim, ao acaso, mas não exatamente.

Um encontro tal qual os encontros cotidianos, mas que pudéssemos intercambiar experiências e trocar impressões sobre o mundo, sobre a cidade em que vivemos sem água, sem luz, sem esgoto, sem ônibus no horário; sobre nossas famílias; sobre nosso trabalho; sobre o último passeio com amigos. Encontro em que trocássemos receitas de comidas, de 
remédios, de maquiagem, de salão de cabeleireiro. Encontros em que combinássemos passeios, comentássemos sobre a novela, compartilhássemos sonhos de ganhar na loteria, de casar, de encontrar um novo namorado. Enfim, encontros de tudo quanto é tipo, cujo assunto nos chegue de repente, flua naturalmente. Encontros que nos fizessem ver que, embora fôssemos diferentes uma da outra, compartilhamos do mesmo mundo e não somos tão diferentes assim, pois temos os mesmo sonhos e desejos: ter uma vida confortável e digna, roupa, casa e comida, filhos com saúde, amigos para conversar e se divertir nos fins de semana.

O local do encontro era a universidade que agora já posso chamar de minha, no horário da tarde, pois, nesse horário, não costuma haver muitos alunos. Os corredores ficam mais calmos, o barulho é menor. Das muitas opções que tinha a meu dispor, escolhi uma sala bem pequena, acreditando que não seríamos interrompidas. Coisa que não se verificou, pois, o tempo todo, éramos interrompidas por alguém que entrava para perguntar se naquele lugar haveria alguma reunião disto ou daquilo. Coisas da vida cotidiana.

Finalmente, olhei para o relógio e tinha chegado a hora. Fui ao encontro da minha interlocutora, uma desconhecida, mas muito a fim de ouvir o que ela tinha para me contar. Todavia, sabia por experiência própria que contar alguma de nossa vida pessoal para quem ainda desconhecemos é uma tarefa, senão difícil, embaraçosa e constrangedora. Precisava, então, encontrar coragem e quebrar o gelo. Usei uma tática. Uma tática que contrariava aquilo que havia prescrito anteriormente, - falar o menos possível -, mas que, naquele momento, se aplicava.

Ao invés de me manter calada ou reticente, fui logo tratando de informar à minha interlocutora que não estava ali para entrevistá-la. Que, antes, estávamos ali para bater um papo, contar e ouvir histórias sobre nossas vidas enquanto mulheres negras e estudantes da pós-graduação. Enquanto mulheres intelectuais. Ansiosa e com a intenção de quebrar a timidez que entre nós já se fazia presente, fui logo falando sobre mim e sobre minhas experiências, na esperança de que ela também começasse a me dizer alguma coisa sobre ela.

Fiquei o tempo todo preocupada em deixá-la bem à vontade, já que tal situação exigia isso. Por fim, o encontro rendeu, pelo menos pra mim, uma produtiva conversa. Apesar de não conhecê-la antes, já nos sentíamos, no decorrer da conversa e ao final, amigas e com certa intimidade. Então, vamos à história que ela me contou.

Joice, pelo que fiquei sabendo por ela mesma, é filha primogênita de pais adolescentes. Talvez por isso, viveu durante dois anos sem certidão ${ }^{\text {iv }}$ de nascimento. Ela brinca comigo dizendo que nasceu sem identidade oficial. Joice também morou em Brasília 
por um breve tempo e muito pequena, de onde não guarda muitas lembranças. Quiçá nenhuma. Depois de Brasília, Joice voltou para sua cidade natal, Nova Iguaçu, lugar que, segundo ela, foi sempre o seu lugar de estudo e de trabalho. Só agora, na pós-graduação, é que foi estudar fora.

Joice passou a nos contar sobre ela a partir de uma experiência bem contemporânea e, portanto, bastante comum a muitas pessoas atualmente. A pesar de ser uma experiência quase corriqueira, seu relato nos mostra como vamos nos revendo e nos acercando de nossas diferenças identitárias. A experiência que Joice nos conta teve a ver com algumas fotos postadas nas páginas do Facebook de sua antiga escola. Conta-nos ela, em suas palavras:

No outro dia, eu estava olhando o Facebook da escola e vi uma fotografia antiga que me chamou a atenção. Era uma fotografia bem comum. Igual àquelas que tirávamos eu e os meus colegas de turma por ocasião de nossa formatura. Nelas, estávamos todos e todas uniformizados e com alguns professores e professoras. Não sei por quê, mas ao olhar para aquela fotografia me deu na telha de contar nos dedos quantos negros/negras havia na turma que eu estudava. Foi aí então que pude constatar que éramos apenas quatro e que, não por acaso, na foto quase era impossível nos perceber naquele grupo de alunas. E, não por acaso, apesar de poucos, naquela fotografia estávamos diluídas como pessoas imperceptíveis. Apesar de andarmos sempre juntas, ali naquela fotografia estamos separadas, quase escondidas no meio daquela pequena multidão de alunos brancos, ou quase brancos. Diante daquele fato, ali registrado e fixado por uma fotografia, me lembrei do meu grupo amigas negras - (eu só tinha amigas negras) - com que conversava, brincava, passeava nos fins de semana.

Foi na observação destas fotografias que me dei conta daquilo que na época eu não percebia. Naquela época de escola eu achava isso natural. Achava que era porque morávamos perto uma das outras e por isso éramos amigas. Mas nesse momento, ao observar esta fotografia, me dei conta que éramos todas segregadas e, por que não afirmar, invisibilizadas. Na época da escola eu não tinha essa noção. Na época pensava que eu não tivesse amigas brancas por ser pobre e, portanto, por não ter condições econômicas para comprar e usar um par de tênis caros ou uma mochila incrementada da moda. Segundo o meu entendimento, o problema não era de preconceito racial, mas econômico-social. Coisas essas que pude perceber claramente ao observar aquela fotografia. [Breve silêncio e Joice suspira fundo]. É, minha amiga, as fotografias não mentem jamais... Elas valem mais que mil palavras.

Depois deste episódio com a fotografia, em que Joice se percebeu negra e discriminada, ela nos contou outras histórias. Outros incidentes cotidianos que confirmam que aquela fotografia não era apenas um mero acaso, mas um caso sério que confirma sua condição de menina de origem negra, afrodescendente. Como é o caso da compra de um simples biscoito uma das calçadas de Nova Iguaçu. Conta-nos ela: 
Fui comprar biscoito amanteigado em uma barraquinha. Uma dessas barraquinhas em que a gente pega os biscoitos e depois pede ao vendedor pesar. Nesse dia, no exato momento que escolhia divertidamente os biscoitos e colocava dentro do saquinho, passou um grupo de meninas da minha escola. Meninas brancas e pertencentes a famílias de renome na cidade. Elas olharam, soltaram alguns risinhos e seguiram em frente. Confesso que naquela hora não tinha entendido o motivo dos risos. Fiquei meio grilada mas não muito. Só no outro dia entendi a causa dos risinhos. O fato, conforme fiquei sabendo, era que aquelas meninas haviam espalhado por toda a escola que eu era camelô; que eu vendia biscoitos na rua para poder pagar as mensalidades da escola. Coisa essa, sim, que me incomodou bastante, não por ter sido confundida com um vendedor de rua, mas por ter sido alvo de chacotas de todos daquela escola.

Essa pequena história de Joice nos exemplifica muito sobre aquilo que aprendemos com Benjamin; não podemos desprezar os pequenos acontecimentos. Nos pequenos acontecimentos, nos sorrisos quase inocentes de um grupo de adolescentes, podem se esconder o racismo e os preconceitos de nossa sociedade. A cena que Joice acabou de nos descrever não é um episódio raro nas sociedades coloniais ou pós-coloniais. O que Joice sofreu neste pequeno e quase insignificante episódio foi aquilo que Bhabha (1998, p. 105) definiu como discursos da fixidez na construção ideológica da alteridade, em que o estereótipo é sua principal estratégia discursiva. Nas palavras de Bhabha, o discurso do estereótipo "é uma forma de conhecimento e de identificação que vacila entre o que está sempre no mesmo lugar, já conhecido, e algo que deve ser ansiosamente repetido".

Foi nesse tipo de discurso que Joice foi vista por aquelas meninas: como uma coisa já interpretada e fixada em um mesmo lugar. Joice está em frente a uma barriquinha de biscoitos e colocando biscoitos em saquinho; logo, Joice, que é uma menina negra e pobre, não pode estar comprando biscoitos; logo, Joice, sem dúvida alguma, é uma camelô. O estereotipo é simples assim, o que não é simples é o que se encontra preso a ele.

Apesar de, hoje, Joice ter consciência e memória bem viva sobre estes pequenos acontecimentos que teve que enfrentar por toda sua vida escolar, só agora, na idade adulta, se deu conta deles. Só depois de observar as tais fotografias percebeu uma diferença que não era só entre pobres e ricos, mas entre pobres brancos e pobres negros. Ela não conseguia ver que os pobres negros não eram só tratados como pobres, mas também como negros; eram tratados como diferentes. Joice avalia que, na época em que estudou naquela escola, desde a Educação Infantil até o Ensino Médio, era muito alienada e só queria ficar ouvindo Jon Bon Jovi, sem dar muito importância a essas coisas. Coisas que encarava como fatos normais, mas que hoje não vê mais assim. Eis o que ela acabou por concluir: 
Hoje, falando sobre meu passado escolar, posso ver e perceber que vivíamos separados em dois grupos: o grupo dos negros e o grupo dos brancos. Embora eu não tenha sofrido tanto quanto as outras meninas mais negras do que eu, pois eu, por ter a pele mais clara, passava por "moreninha". Por ter sido classificada assim, como moreninha, é que escapei de ser chamada de macaca, de cabelo de Bombril ou ser considerada uma empregada que servia só para limpar o chão, conforme minhas amigas. Atitudes essas que hoje me dou conta que eram atitudes racistas contra as minhas amigas, mas a mim também. Hoje sei que, ao ser tratada como moreninha, era uma forma velada de também ser discriminada. Uma quase igual a eles, mas não exatamente igual. $\mathrm{O}$ fato é que presenciei com meus próprios olhos várias atitudes racistas de professores contra alunos, de alunos contra alunos. E dos alunos contra uma professora de inglês, que meus colegas apelidaram de Mary Black, Maria Preta. Uma pessoa, a meu ver, adorável e cordata, que nunca discutia, que nunca reclamava, mas que, não sei por que cargas d'água, acabou pedindo demissão e foi embora da escola de um dia para outro. $\mathrm{O}$ que terá acontecido com ela? É o que tenho me perguntado ultimamente.

Todavia, a história de Mary Black não é só história dela, mas de muitas mulheres negras. Uma história bem parecida aconteceu comigo quando, por certo tempo, fui diretora de uma escola da rede de Nova Iguaçu. Durante o tempo em que fui diretora, me vestindo como você está me vendo aqui, de leg, sapatilha, muitas das vezes em que me encontrava no portão, as pessoas chegavam e pediam para falar com a diretora. Isso aconteceu muitas vezes, e quando perto de mim se encontrava uma professora branca, eles se dirigiam a ela como se ela fosse a diretora. Isso é uma coisa que eu levava na brincadeira mas me incomodava.

As histórias que nos foram contadas por Joice são histórias vividas por Joice, mas que podem mesmo, assim únicas e particulares, serem vistas como histórias comuns entre as mulheres negras. O problema a ser enfrentado não pode ser visto apenas pela vertente socioeconômica, mas também pela vertente racial, pelo pertencimento. Como se pode perceber na história de Mary Black, uma negra que fala inglês, ou na sua experiência de diretora, apesar de andar bem vestida e ser moreninha, ela não era vista como tal. Em ambos os casos, foi o discurso do estereótipo que agiu: se é negra não pode falar inglês, se é negra não pode ser a diretora. Negra é negra; logo, Mary Black está fora do seu lugar, não pode ser professora, ainda mais de uma língua estrangeira. Joice pode ser professora e, apesar de bem vestida, não pode ser diretora. Porém, o mais estranho disso tudo é que essas coisas não impregnam apenas a cabeça dos brancos. Elas atingem a subjetividade de nós, negros e negras, fazendo-nos pensar que somos incapazes de ocupar outros lugares na sociedade. É o que se pode verificar ao final da entrevista, quando perguntei a Joice se ela se considerava uma mulher intelectual. Na hora, a resposta ficou no ar, mas chegou depois por e-mail: 
Prezada Neuza,

Durante nossa conversa, você levantou uma questão a respeito se eu me considerava uma intelectual. Levantou uma questão que eu tenho comentado com outras/os colegas até hoje: eu me reconheço como intelectual? Nossa! Como isto mexeu comigo. Não de forma negativa, longe disso, mas, simplesmente porque nunca pensei nisso. Durante toda a minha formação aprendi a admirar aqueles que produziam os livros não didáticos. Quem escreve contos, poesias, crônicas. Admiro compositores de música, admiro quem produz saber. E eu nunca me incluí neste grupo. O fato é que saí da conversa mexida e estimulada.

O e-mail de Joice, embora ainda não tenha nos dado uma resposta definitiva (essa resposta não existe), confirma a força do encontro e do diálogo. Do diálogo ninguém sai como entrou. Sai alterado.

\section{Palavras finais continuando a conversa.}

Os encontros me levaram a lugares que eu desconhecia. As muitas outras histórias que ouvi e que, por uma questão de tempo, não poderei contar neste momento, estão guardadas e, com certeza, surgirão em outros momentos de minha caminhada acadêmica. Fui para o encontro em busca de um diálogo, mas queria ouvir mais que falar. Nesta escuta sensível e responsável, pude perceber que algumas questões eram comuns a todas as mulheres com quem conversei. Por isso, decidi colocar uma lente de aumento em comentários. Comentários que, na maioria das vezes, poderiam nos passar despercebidos. Por isso, decidi deixá-los para o final, como uma espécie de análise de dados.

\section{* Eu lá teria filho com mulher preta: as relações afetivas e estéticas das mulheres negras.}

Os encontros foram riquíssimos. Os diálogos que construímos ajudaram-me a pensar sobre a vida e as condições de ser mulher negra e intelectual em uma sociedade como a nossa, machista, branca e sexista. No decorrer dessas escutas, dois aspectos tornaram-se bem evidentes: as relações afetivas e estéticas. O que é interessante é que, inicialmente, elas não eram questões importantes para mim. Não conseguia ver essa relação entre elas. Só após reler as transcrições percebi que toda mulher quer ser amada, benquista e aceita na e pela sociedade em que vive. Percebi que toda mulher quer ser bonita. Que toda mulher quer, sobretudo, ser feliz, assim como o quer e deseja todo e qualquer ser humano. E que, portanto, as questões 
estéticas e afetivas não são uma coisa banal e sem importância. São estas questões, e não outras, as mais fundamentais para se combater o racismo e o preconceito contra as mulheres. São estas, e não outras, a grande questão que teremos de enfrentar.

Em "Vivendo de amor", Bell Hooks ${ }^{\mathrm{v}}$ traz para nós uma bela discussão sobre relações afetivas de mulheres negras. A autora afirma que esta questão é extremamente delicada, e que muitas pesquisas omitem tais dados, como se nós, mulheres negras, não fôssemos capazes de receber e dar amor.

Muitas mulheres negras sentem que, em suas vidas, existe pouco ou nenhum amor. Essa é uma de nossas verdades privadas, que raramente é discutida em publico. Essa realidade é tão dolorosa que as mulheres negras raramente falam abertamente sobre isso. (HOOKS, 2010, s/p).

Minhas interlocutoras falaram, mesmo quando não explicitamente, de amor. Porque toda mulher não pode viver sem amor. Falaram do amor entre mães e filhos. Falaram do amor entre avós e netas. Falaram do amor entre elas e os homens que tiveram ou não tiveram. Porém, ao falar desse amor, elas trouxeram à baila dados que corroboram a triste constatação de Franz Fanon (2008, p. 34): "todo homem negro só quer um pouco de brancura da mulher branca". Tese essa que se confirma na história contada por Joice, mas que não incluímos em seu relato anterior.

Eu namorei um menino negro por algum tempo. Aí terminamos nosso relacionamento, mas ficamos amigos. Nesse período de separação, ele engravidou uma menina branca. Aí, passado um tempo, ele veio me mostrar a foto da filha dele e disse:

- Minha filha é linda, não é?

Aí eu respondi:

- É linda sim, mas se fosse minha seria muito mais bonita.

Aí ele respondeu:

- E eu faço filho em mulher preta?

Já Anna, em um tom de reclamação no meio da conversa, afirma: "Meu namorado insiste em dizer pra mim que eu não sou negra, sou moreninha”.

Por que não ter filhos com uma mulher negra? Por que um homem precisa negar a negritude que a sua própria parceira enuncia?

A ideia do branqueamento vem sendo a cada dia reafirmada, e a rejeição do corpo negro pelo negro pode ser verificada nos relatos acima. Neste caso, estamos diante de uma 
rejeição que se projeta no futuro, nos descendentes que poderão vir. Voltando ao questionamento: por que não ter filhos com uma mulher negra?

Ter filhos com uma mulher branca, além de "clarear a raça", "clarear a família", como ouvi muitas vezes em conversas com meus familiares, é uma necessidade real. Dois pontos são fundamentais nessa discussão: o negro é o ser destituído de beleza, e o branco é o sinônimo da mais bela e pura beleza, além de dominar "os meios de comunicação, a mídia, os lugares de poder, a informação e a escolarização" (GOMES, 2008 p. 129).

Ter "traços mais finos", isso é, ter um rosto com características estéticas de um branco, é sinônimo de beleza. Dandara disse: "Quando eu era criança, falavam que minha irmã era mais bonita que eu, pois ela tinha traços finos e eu tinha uma aparência grosseira, lábios mais carnudos, nariz achatado".

Fanon fala do desejo quase patológico do negro de se tornar branco. A ideia do branqueamento pode ser percebida no relato em que o homem negro não deseja ter filhos com uma mulher igualmente negra, pois uma mulher branca pode trazer-lhe a tão sonhada brancura.

Da parte mais negra de minha alma, através da zona de meias-tintas, me vem este desejo repentino de ser branco. Não quero ser reconhecido como negro, e sim como branco. Ora - e nisto há um reconhecimento que Hegel não descreveu - quem pode proporcioná-lo, senão a branca? Amando-me ela me prova que sou digno de um amor branco. Sou amado como um branco. Sou um branco. Seu amor abre-me o ilustre corredor que conduz à plenitude... Esposo a cultura branca, a beleza branca, a brancura branca. Nestes seios brancos que minhas mãos onipresentes acariciam, é da civilização branca, da dignidade branca que me aproprio. (FANON, 2008, p. 69)

O cabelo do negro também aparece nos relatos sobre estética e afeto, já que, para ter uma boa aparência, é preciso ter os cabelos parecidos com os cabelos das brancas. O relato a seguir ilustra essa afirmação.

Quando comecei a trabalhar como professora no Estado, eu não usava químicas no cabelo. Mas percebia que não era bem aceita pelos meus alunos e pelos meus colegas de trabalho. Ouvia comentários dos meus alunos e colegas sobre meu cabelo. $\mathrm{Na}$ época, eu não tinha discurso para rebater aquelas críticas. Então, foi aí que eu comecei a usar química em meus cabelos e percebi que a relação começou a mudar. Meus colegas começaram a me tratar diferente, eu fazia parte do grupo. Hoje percebo que eu poderia ser um exemplo para minhas alunas e, por isso, decidi deixar de passar 
química no cabelo. E sinto que hoje já tenho um contradiscurso do por que usar o cabelo assim. (DANDARA ${ }^{\mathrm{vi}}$ )

Quando Dandara se inseriu em grupos de pesquisa que discutiam relações étnicoraciais, percebeu que estava habilitada para enfrentar esses conflitos e assumir outra forma estética, segundo a qual suas alunas poderiam ver nela um exemplo de beleza.

A beleza pode ser, então, entendida como uma categoria estética e construção social, como uma maneira de nos relacionarmos com o mundo. Ela não tem a ver com formas, medidas, proporções, tonalidade, arranjos pretensamente ideais que definem algo como belo. Sendo assim, beleza não se refere às qualidades dos objetos mensuráveis, quantificáveis e normatizáveis. Ela diz respeito à forma como nos relacionamos com eles, por isso ela é a relação entre sujeito e objeto. (GOMES, 2008, p. 281)

Nossas relações afetivas e estéticas foram construídas em meio a uma ideia colonial de beleza. Por isso, muitas vezes não aceitamos o que vemos no espelho. Um movimento contrahegemônico se faz necessário. Porém é preciso, primeiro, iniciar o processo de amor interior. Digo "amor interior" e não "amor próprio" porque, assim como hooks propõe, a palavra "próprio" é geralmente usada para definir nossa posição em relação aos outros. Numa sociedade racista e machista, a mulher negra não aprende a reconhecer que sua vida interior é importante.

Onde está o amor, quando uma mulher negra se olha e diz: "Vejo uma pessoa feia, escura demais, gorda demais, medrosa demais - que não merece ser amada, porque nem eu gosto do que vejo". Ou talvez: "Vejo uma pessoa tão ferida, que é pura dor, e não quero nem olhar pra ela porque não sei o que fazer com essa dor". Aí o amor está ausente. Para que esteja presente, é preciso que essa mulher decida se olhar internamente, sem culpa e sem censura. (HOOKS, 2010, s/p)

Nós, mulheres negras, precisamos de mais amor em nossas vidas. Não somente o amor entre pessoas, mas o amor interior. E o mais importante: é preciso fazer com que os outros nos respeitem, nos amem do jeito que somos.

Eu poderia simplesmente omitir esta discussão do meu trabalho, pois, confesso, ela mexe diretamente com o meu interior. Porém, assumir a necessidade de amor em nossas vidas é uma forma de ir contra a opressão, porque somente nós podemos "transformar o mundo no lugar onde gostaríamos de viver”. Um mundo mais justo e mais belo. A justiça só pode vir de forma amorosa. Onde há amor, não falta nada. Quem ama verdadeiramente não tem 
preconceito. $\mathrm{O}$ amor é a porta e a chave, a entrada e a saída para o mundo que desejo. Eu não devo amar o outro só porque ele é bonito. Ele é bonito porque eu o amo. O amor é segredo que não deve ser guardado.

\section{** Intelectuais são os outros, eu não!}

No ano de 2013, o governo brasileiro começou a desenvolver uma política denominada "Mais Médicos". Tal política objetivou trazer médicos de outras nacionalidades, formados fora do país, para trabalhar em lugares onde os médicos brasileiros recusam-se a trabalhar. Não é nosso objetivo discutir se tal política é certa ou errada. O que quero discutir é a posição que a mulher negra ocupa na sociedade, e a chegada das médicas cubanas ajuda-nos a ilustrar esse painel.

Quando os primeiros médicos e médicas chegaram ao país - foram os cubanos -,os aeroportos estavam lotados de médicos brasileiros protestando, além de jornalistas cobrindo tal chegada. E, em uma rede social, uma jornalista manifestou suas impressões sobre a chegada desses médicos, especialmente sobre as médicas cubanas.

A publicação da jornalista dizia que as médicas cubanas pareciam empregadas domésticas, que não tinham aparência de médicas. Afirmava que, para ser médico, era preciso ter postura (apesar de não explicitar qual é essa postura), o que aquelas mulheres não tinham. Questionava, assim, se as cubanas recém-chegadas eram realmente médicas. Concluía que "quem sofreria com a chegada das médicas cubanas seria o povo".

O que a jornalista escreveu somente reforçou os estereótipos que vivenciamos e contra os quais lutamos todos os dias. Nós, negras, não podemos ser intelectuais; ou melhor, não podemos sequer exercer uma posição de prestígio, pois esse não é o nosso lugar, Reiteram-se, assim, mais uma vez, as palavras do eminente sociólogo Gilberto Freyre: as mulheres negras são boas para cama ou para cozinha. No primeiro caso, prostitutas; no outro, servas. Em ambos os casos, nega-se o amor.

Bell Hooks contribui para essa discussão com elementos que constituíram a cultura estadunidense e que são semelhantes aos de nossa realidade, já que a parte sul dos Estados Unidos também se utilizou de seres humanos negros escravizados.

Para justificar a exploração masculina branca e o estupro das negras durante a escravidão, a cultura branca teve de produzir uma iconografia de corpos de negras que insistia em representá-las como altamente dotadas de sexo, a perfeita encarnação de um erotismo primitivo e desenfreado. Essa 
representações incutiram na consciência de todos a ideia de que as negras eram só corpo, sem mente. A aceitação cultural dessas representações continua a informar a maneira como as negras são encaradas. Vistos como "símbolos sexual", os corpos femininos negros são postos numa categoria, em termos culturais, tida como bastante distante da vida mental. Dentro das hierarquias de sexo/raça/classe dos Estados Unidos, as negras sempre estiveram no nível mais baixo. (HOOKS, 1995. p. 469)

Além de símbolo sexual, a mulher negra carrega o estereotipo de "mãe preta". Quando não somos "prostitutas", recebemos a função de cuidar dos outros, em especial dos mais ricos.

Do outro lado das representações das negras como selvagens sexuais desqualificadas e/ou prostitutas, há o estereotipo da "mãe preta". Mais uma vez, essa imagem registra a presença feminina negra como significada pelo corpo, neste caso a construção de mulher como mãe, "peito", amamentando e sustentando a vida de outros. Significativamente, a proverbial "mãe preta" cuida de todas as necessidades dos demais, em particular dos mais poderosos. (Idem)

O comentário da jornalista está alicerçado nesse segundo paradigma que hooks nos apresenta: a mulher negra não pode ser médica, engenheira ou intelectual, pois nascemos para cuidar dos outros. Hooks afirma que, nos lares dos estadunidenses, quase não existem empregadas domésticas. Porém, as mulheres que ocupam diversas funções no mercado de trabalho queixam-se de que lhes é cobrado esse cuidado materno em suas funções. A aceitação passiva desses papéis pode ser um dos motivos que impedem que as mulheres negras escolham tornar-se intelectuais, afirma a autora.

Quando encontrei com minhas interlocutoras, em meio a nossas conversas, questionei se elas eram intelectuais. A minha pergunta foi recebida com bastante estranheza e elas responderam coisas como:

Não me considero intelectual, me considero uma estudante.

Intelectual pra mim é aquele cara que escreve livros, faz poemas.

Aquele cara que escreve livro é o autor do livro. Apesar de saber que eu posso produzir também e produzo.

Intelectual é o escritor, o poeta renomado, mas nunca me coloquei como intelectual. Mas almejo bastante um dia ser.

Intelectual é o professor. Mas não qualquer professor, talvez o professor universitário. 
Minhas interlocutoras negam o título de intelectuais, dizendo que um dia poderão ser. Porém, eu só as escolhi por acreditar que já são intelectuais. Meu trabalho fala da formação intelectual de mulheres negras, e se as elegi para participar é porque as considero com tais. $\mathrm{O}$ fato é que existem representações de intelectuais. O intelectual pode se manifestar de várias formas. $\mathrm{Eu}$ acredito que uma dessas representações, em nossa sociedade atual, é estar cursando a pós-graduação stricto sensu. E não só isso. Minhas interlocutoras possuem objetos de pesquisas que eu acredito que sejam de transgressoras, pois estudar negras, negros e homossexuais é formar transgressão em uma sociedade e academia machistas, homofóbicas e sexistas.

Fui buscar em Hooks uma explicação para essa negação. Ao relatar sua infância e a forma como foi criada, a autora me fez relembrar fatos de minha infância e que, consequentemente, me ajudaram a refletir e compreender sobre o meu momento atual.

É bem verdade que nós, mulheres, em especial as negras e pobres, fomos criadas para aprender a ser mãe, ou seja, para concretizar, ou melhor, reforçar o paradigma da "mãe preta". As tarefas domésticas sempre vieram em primeiro lugar. Não tínhamos tempo, durante a infância, para o exercício de pensar. Recordo-me de que, quando criança, preferia ficar sozinha e me afastava de meus irmãos e primos. Minha mãe logo me chamava e dizia que não queria ver ninguém sozinho na casa dela.

A tarefa do pensar se tornou menor, porque primeiro era preciso cuidar da casa e, posteriormente, conversar, estar junto com a família. Uma de minhas interlocutoras relata sobre a dificuldade que encontra em estudar em sua casa.

A ideia do mestrado é muito bacana, mas ninguém respeita quando eu estou estudando para o mestrado. Eu não consigo estudar, não consigo estudar em casa. Vou para o CEDERJ todos os dias. Eles ficam [dizendo] "sai desse computador, você não sai desse computador, você não dá mais atenção a sua família” etc. Não é só da família, mas dos amigos também. Já fui rejeitada pelo meu namorado, porque ele acha que dou mais valor ao mestrado que [a] ele. Mas essa fase passa, eu sei que passa. (JOICE)

O trabalho intelectual exige um distanciamento, um isolamento. Escrever é uma atividade solitária, e para nós, que fomos criadas em meio a um grupo que valoriza o trabalho não intelectual em detrimento do trabalho intelectual, é extremante difícil. Hooks afirma que muitas alunas negras estadunidenses abandonam os cursos de graduação no momento em que, para concluir, é preciso escrever suas teses. 
Concentrando-me particularmente em negras que concluíram cursos universitários, mas o interromperam no estágio de escrever a tese final, descobri que eram as mais enredadas em sentimentos contraditórios sobre o valor acadêmico e/ou trabalho intelectual, e que esses sentimentos bloqueavam psicologicamente sua capacidade de concluir essa exigência final. (HOOKS, 1995, p. 471)

Não se considerar intelectual não é culpa de minhas interlocutoras. Na verdade, atribuo essa tal dificuldade ao bloqueio psicológico que sofremos, pois me coloco nesta situação; consequentemente, não nos reconhecemos como tal. Indo mais fundo na questão, se quisermos nos tornar intelectuais de fato, precisamos descolonizar os nossos pensamentos, pois, enquanto deixarmos nossas mentes presas a um contexto social capitalista de supremacia patriarcal branca, nosso processo intelectual não será intensificado. É preciso intensificar, romper com as amarras. E eu, mais que todas. E todas mais que eu. Quem sabe juntas... Que o amor, enfim, nos una!

\section{Referências bibliográficas.}

AMORIN, Marilia. O pesquisador e seu outro: Bakhtin nas ciências humanas. São Paulo: Musa Editora, 2004.

ARENDT, Hannah. A condição humana. Tradução: Roberto Raposo, 11ed. Rio de Janeiro: Forense universitária, 2010.

BAKHTIN, Mikhail (Voloschinov). Marxismo e filosofia da linguagem. 6a. ed. São Paulo: Hucitec, 1995.

BAKHTIN, Mikhail. Estética da Criação Verbal. São Paulo: Martins Fontes, 2011.

BENJAMIN, Walter. Magia e técnica, arte e política: ensaios sobre literatura e história da cultura. São Paulo: Brasiliense, 1985.

FANON, Frantz. Peles negras, máscaras brancas. Salvador: EDUFBA, 2008.

GOMES, Nilma Lino. Sem perder a raiz: corpo e cabelo como símbolo da identidade negra. $2^{\mathrm{a}}$ ed. Belo Horizonte: Autêntica, 2008.

HOOKS, B. Intelectuais Negras. Revista Estudos Feministas, V.3, nº 2, 1995, p. 454-478. . Vivendo de amor. In: Geledes, 2010, s/p. Disponível em: http://arquivo.geledes.org.br/areas-de-atuacao/questoes-de-genero/180-artigos-degenero/4799-vivendo-de-amor Acesso: março de 2015. 
${ }^{\mathrm{i}}$ Universidade Federal Rural do Rio de Janeiro

${ }^{\text {ii }}$ As outra duas histórias podem ser encontradas no site: http://cursos.ufrrj.br/posgraduacao/ppgeduc/dissertacoes-defendidas/

iii Joice é graduada em Pedagogia pelo Centro de Educação a Distância do Estado do rio de Janeiro (CEDERJ/UERJ) e atua como professora na rede municipal de Nova Iguaçu.

iv Em termos jurídicos, a certidão de nascimento é a primeira "identidade".

${ }^{v} \mathrm{O}$ texto aqui referido foi traduzido por Maísa Mendonça. Disponível em: http://www.geledes.org.br/areas-deatuacao/questoes-de-genero/180-artigos-de-genero/4799-vivendo-de-amor. Acesso em julho de 2013.

${ }^{\mathrm{vi}}$ Dandara é uma das mulheres que encontrei, e que futuramente contarei sua história. 